\title{
Association between religiosity and functional capacity in older adults: a systematic review
}

\author{
Diane Nogueira Paranhos Amorim? \\ Clarrissa Marrreiros Lages da Silveira' \\ Vicente Paulo Alves' \\ Vicente de Paula Faleiros' \\ Karla Helena Coelho Vilaçal
}

\section{Abstract}

Objective: To verify the association between religiosity and functional capacity in the elderly. Method: a systematic review of literature in the SciELO, Lilacs, MEDLINE/ PubMed and the portal of CAPES Journals databases was performed. The descriptors were selected through the list of Descriptors in Health Sciences (Decs) and Medical Subject Headings (Mesh). Original articles in Portuguese and English, published between 2007 and 2017, with a sample composed of elderly persons aged 60 years or more were included. Systematic or integrative reviews, case studies, scale validation studies, dissertations and theses and studies on religious social support were excluded, as well as articles that included elderly persons and adults in the sample. Result: 280 articles were identified, of which six were included in this review. Religiosity was associated with improved functional capacity and coping with disability and the delay of functional decline in the elderly. Different aspects of religiosity were associated with functional capacity, such as participation in religious activities, religious leadership role performance and religious beliefs and traditions. In three articles the positive association between religiosity and functional capacity was linked only to public religious activities and not to intrinsic religious practices. Conclusion: religiosity is significantly and positively associated with the functional capacity of the elderly. The association between intrinsic religiosity and functional capacity is still unclear.

\footnotetext{
Universidade Católica de Brasília, Escola de Medicina, Programa de Pós-graduação Stricto Sensu em Gerontologia. Brasília, DF, Brasil

Research Funding: Fundação de Apoio à Pesquisa do Distrito Federal (Distrito Federal Research Support Foundation) (FAP/DF). Doctoral Scholarship from PMD/UCB/FAPDF 2017 Program, No 24/2017.

Correspondence

Diane Nogueira Paranhos Amorim.

E-mail: diannenogueira@hotmail.com
}

Keywords: Elderly. Religion. Spirituality. Activities of Daily Living 


\section{INTRODUCTION}

The development of a long-lived population has revealed the importance of understanding human aging which, despite being a process characterized by physical and biological alterations, also causes changes in the psychological, relational and social dimensions ${ }^{1}$.

Since the World Health Organization (WHO) recognized the psychosocial dimensions of health and quality of life, certain aspects have begun to be considered in the evaluation and promotion of health ${ }^{2}$. In the elderly population, one of these aspects is religiosity, which has a variety of implications for the health/disease process ${ }^{3}$.

Religiosity is how much an individual believes, follows, and practices a religion. It can be practiced publicly, in an organized (participation in a church or temple) or non-organized (participation in activities outside a religious institution) manner, and/or intrinsically ${ }^{4}$ (prayers and orisons, readings, meditations).

The relationship between the different aspects of religiosity and health in the elderly is of gerontological interest. Some studies have already described the association between religious practice and mortality and physical and mental health ${ }^{5,6}$. In the elderly, it should be considered that physical and mental health is closely linked to functional capacity, a new and important paradigm in health and aging ${ }^{7}$.

The functional capacity of the elderly can be understood as the ability to perform, with autonomy and independence, the basic activities of daily living (BADL), linked to self-care, and instrumental activities of daily living (IADL) related to an independent life in the community ${ }^{7}$.

While a decline in functional capacity is accepted with advancing age, maintaining independence facilitates the life of the elderly person within the family and social environment ${ }^{8}$. The frequency and intensity of this decline vary greatly, and are associated with gender, cognition, educational level, general health conditions and use of medications ${ }^{9,10}$.
Psychosocial aspects also play an important role in this process and have been described as factors associated with functional capacity. According to Kagawa and Corrente, quality of life, self-knowledge and participation in the community influence the performance of BADL and IADL. For Nogueira et al. ${ }^{10}$, non-socialization and a more negative selfperception of health are positively associated with reduced functional capacity.

Considering the importance of functional capacity as an indicator of health for the elderly and religiosity as a psycho-sociocultural dimension of great significance in the daily life of such individuals, it is useful to research and understand the benefits that this dimension can offer to the elderly. The objective of this article, therefore, was to verify the association between religiosity and functional capacity in the elderly through a systematic review of articles related to the theme.

\section{METHODS}

A systematic review of literature was carried out based on the following guiding question: What is the association between religiosity and functional capacity in the elderly? The search for articles was carried out in April 2017 in the SciELO, Lilacs, MEDLINE/ PubMed and CAPES Periodicals Portal databases.

Descriptors in Portuguese and English were used in the article search. These were divided into two categories: category 1) elderly (idoso), functionality (funcionalidade), disability (incapacidade), activities of daily living (atividades de vida diária) and day to day activities; and category 2) religion (religião) and spirituality (espiritualidade). Each term in category 1 was combined with a category 2 term (of the same language), using the Boolean operator "AND", until all combinations had been made.

The descriptors were selected from the lists of the Descriptors in Health Sciences (Decs) and the Medical Subject Headings (Mesh).

Original articles in Portuguese and English, published between 2007 and 2017, with a sample 
composed of elderly individuals aged 60 years or older, were included. Systematic or integrative reviews, case studies, validation of scales studies, dissertations and theses, and studies on religious social support were excluded, as were articles that included elderly and non-elderly adults in their samples.

The article searches and selection process was performed by two independent reviewers with a third evaluator requested in cases of disagreement. After consulting the databases, duplicate studies from more than one database were excluded. Analysis by title and subsequently abstract was carried out, which allowed the exclusion of further studies. The selected studies were read in full and included in the review in accordance with the inclusion and exclusion criteria. An active manual search of the references of the included studies was also performed.
The data were extracted and input into a standard form, adapted from the Cochrane Collaboration ${ }^{11}$.

\section{RESULTS}

Although the initial search using the descriptors identified 280 articles, only six were included in this systematic review. The methods used and the excluded articles are summarized in Figure 1.

Among the included studies, only one was qualitative $^{3}$ and the others were quantitative. Two articles had a cross-sectional design ${ }^{12,13}$, three were longitudina $1^{14-16}$ and one was an observational ethnographic study ${ }^{3}$. Five studies ${ }^{12-16}$ were conducted in the United States and only one was carried out in Brazil $^{3}$ (Chart 1).

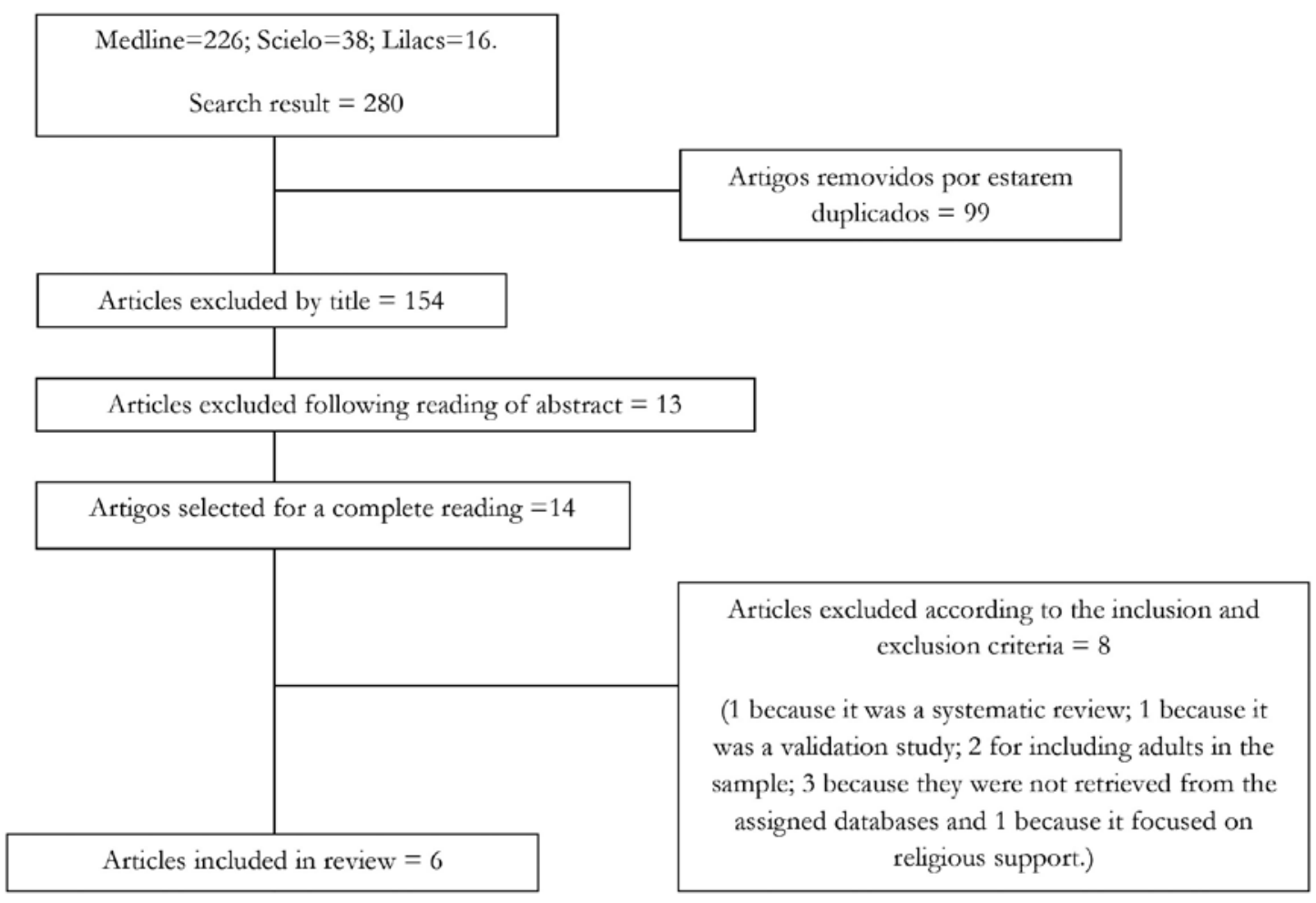

Figure 1. Flowchart of inclusion and exclusion of data. Brasília, Distrito Federal, 2017. 
Chart 1. Summary of studies selected for review. Brasília, Distrito Federal, 2017.

\begin{tabular}{|c|c|c|c|c|c|}
\hline Reference & $\begin{array}{l}\text { Journal; } \\
\text { Year; } \\
\text { Location }\end{array}$ & Design & $\begin{array}{l}\text { Instruments used to } \\
\text { evaluate functional } \\
\text { capacity and religiosity }\end{array}$ & Sample & Main findings \\
\hline $\begin{array}{l}\text { Santos et } \\
\text { al. }^{3}\end{array}$ & $\begin{array}{l}\text { Ciência } \\
\text { \& Saúde } \\
\text { Coletiva } \\
\text { (Science and } \\
\text { Collective } \\
\text { Health); } \\
\text { 2013; } \\
\text { Bambuí, } \\
\text { Minas Gerais }\end{array}$ & $\begin{array}{l}\text { - Ethnographic } \\
\text { observational } \\
\text { - Qualitative }\end{array}$ & $\begin{array}{l}\text { Semi-structured } \\
\text { interview in which the } \\
\text { elderly were asked to talk } \\
\text { about life and about their } \\
\text { health conditions and } \\
\text { eventual experience of } \\
\text { functional disability. }\end{array}$ & $\begin{array}{l}57 \text { elderly persons } \\
\text { registered in a Basic } \\
\text { Health Unit } \\
\text { - Saturation } \\
\text { criterion used to } \\
\text { regulate sample size }\end{array}$ & $\begin{array}{l}\text { Religious beliefs and } \\
\text { traditions have proven } \\
\text { to be an important } \\
\text { tool for coping with } \\
\text { disability }^{4}\end{array}$ \\
\hline $\begin{array}{l}\text { Berges, } \\
\text { Kuo and } \\
\text { Markides }^{12}\end{array}$ & $\begin{array}{l}\text { Experimental } \\
\text { Aging Research } \\
-2007 \\
\text {-Texas, USA }\end{array}$ & $\begin{array}{l}\text { - Cross- } \\
\text { sectional } \\
\text { - Quantitative }\end{array}$ & $\begin{array}{l}\text { - BADL and IADL: } \\
\text { Katz index, Guttman } \\
\text { functional health scale. } \\
\text { - Functional Mobility: } \\
\text { Performance Oriented } \\
\text { Mobility Assessment } \\
\text { (Poma) } \\
\text { - Religiosity: direct } \\
\text { question "how often do } \\
\text { you attend church or } \\
\text { religious activities?" }\end{array}$ & $\begin{array}{l}118 \text { non- } \\
\text { institutionalized } \\
\text { Hispanic adults (of } \\
\text { Mexican origin), who } \\
\text { had suffered a stroke } \\
\text { - Representative } \\
\text { sample of around } \\
500,000 \text { Hispanic } \\
\text { elderly persons }\end{array}$ & $\begin{array}{l}\text { Frequent participation } \\
\text { in religious activities } \\
\text { was associated with } \\
\text { a reduced decline in } \\
\text { the performance of } \\
\text { BADLs }(p=0.017) \\
\text { and IADLs }(p=0.05) \\
\text { in the elderly post- } \\
\text { stroke. }\end{array}$ \\
\hline $\begin{array}{l}\text { Arcury et } \\
\text { al. }^{13}\end{array}$ & $\begin{array}{l}\text { The Journal of } \\
\text { Rural Health } \\
-2013 \\
\text {-North } \\
\text { Carolina, } \\
\text { USA }\end{array}$ & $\begin{array}{l}\text { - Transversal } \\
\text { - Quantitative }\end{array}$ & $\begin{array}{l}\text { - BADL and IADL: } \\
\text { Medical Outcomes Study } \\
\text { (MOS) functionality } \\
\text { scale } \\
\text { - Religiosity: the authors } \\
\text { created questions and } \\
\text { scores about public } \\
\text { and private religious } \\
\text { practices. }\end{array}$ & $\begin{array}{l}701 \text { elderly diabetics } \\
\text { from rural areas with } \\
\text { different ethnicities } \\
\text { (American, African } \\
\text { American and white) } \\
\text { - Randomized, } \\
\text { stratified sample. }\end{array}$ & $\begin{array}{l}\text { Improved functional } \\
\text { capacity was } \\
\text { associated with public } \\
\text { religious practices } \\
(p<0.05) \text {. There } \\
\text { was no association } \\
\text { between functional } \\
\text { capacity and intrinsic } \\
\text { religious practices. }\end{array}$ \\
\hline Park et al. ${ }^{14}$ & $\begin{array}{l}\text { Research on } \\
\text { aging } \\
-2008 \\
\text {-Alabama, } \\
\text { USA }\end{array}$ & $\begin{array}{l}\text {-Observacional } \\
\text { longitudinal } \\
\text { - Quantitative }\end{array}$ & $\begin{array}{l}\text { - BADL and IADL: } \\
\text { Lawton Scale. } \\
\text { - Religiosity: Duke } \\
\text { Religiosity scale } \\
\text { (DUREL) }\end{array}$ & $\begin{array}{l}784 \text { American elderly } \\
\text { persons living in the } \\
\text { community } \\
\text { - Sample stratified } \\
\text { by municipal region, } \\
\text { ethnicity and gender. }\end{array}$ & $\begin{array}{l}\text { The frequent } \\
\text { participation in } \\
\text { religious activities } \\
\text { was associated with } \\
\text { less difficulty in } \\
\text { the performance } \\
\text { of BADLs ( } p \\
=0.001) \text { and IADLs } \\
(p=0.05) \text {, however, } \\
\text { a longitudinal } \\
\text { protective effect was } \\
\text { detected only for } \\
\text { IADLs }(p=0.05) \text {. }\end{array}$ \\
\hline
\end{tabular}


continued from Chart 1

\begin{tabular}{|c|c|c|c|c|c|}
\hline Reference & $\begin{array}{l}\text { Journal; } \\
\text { Year; } \\
\text { Location }\end{array}$ & Design & $\begin{array}{l}\text { Instruments used to } \\
\text { evaluate functional } \\
\text { capacity and religiosity }\end{array}$ & Sample & Main findings \\
\hline $\begin{array}{l}\text { Hybels et } \\
\text { al. }^{15}\end{array}$ & $\begin{array}{l}\text { The } \\
\text { Gerontologist } \\
-2012 \\
\text {-North } \\
\text { Carolina, } \\
\text { USA }\end{array}$ & $\begin{array}{l}\text { - Longitudinal } \\
\text { - Quantitative }\end{array}$ & $\begin{array}{l}\text { - BADL and IADL: } \\
\text { Katz index, Fillenbaum } \\
\text { scale. } \\
\text { - Functional mobility: } \\
\text { Guttman functional } \\
\text { health scale. } \\
\text { - Religiosity: direct } \\
\text { question "how often } \\
\text { do you go to religious } \\
\text { events?", "how often } \\
\text { do you watch or listen } \\
\text { to religious programs } \\
\text { on TV or the radio?", } \\
\text { how often do you spend } \\
\text { time on private religious } \\
\text { activities such as praying, } \\
\text { medication or religious } \\
\text { study?" }\end{array}$ & $\begin{array}{l}2.924 \text { elderly } \\
\text { Americans living in } \\
\text { the community } \\
\text {-Representative } \\
\text { sample of five } \\
\text { municipal regions in } \\
\text { the state of North } \\
\text { Carolina }\end{array}$ & $\begin{array}{l}\text { A greater frequency } \\
\text { in religious activities } \\
\text { was associated with } \\
\text { reduced limitations } \\
\text { in BADLs, IADLs } \\
\text { and in mobility } \\
(p<0.0001) \text {. Watching } \\
\text { religious programs } \\
\text { on TV or listening } \\
\text { on the radio was } \\
\text { associated with the } \\
\text { greater development } \\
\text { of limitations in } \\
\text { IADLs and mobility } \\
\text { ( } p<0.0001), \text { in } \\
\text { an uncontrolled } \\
\text { analysis.* Intrinsic } \\
\text { religious practice was } \\
\text { not associated with } \\
\text { functional changes. }\end{array}$ \\
\hline $\begin{array}{l}\text { Hayward } \\
\text { and } \\
\text { Krause }^{16}\end{array}$ & $\begin{array}{l}\text { Journal of } \\
\text { Behavioral } \\
\text { Medicine } \\
-2014 \\
\text { - USA }\end{array}$ & $\begin{array}{l}\text { - Longitudinal. } \\
\text { - Quantitative. }\end{array}$ & $\begin{array}{l}\text { - BADL and IADL: } \\
\text { based on } 15 \text { items of the } \\
\text { BADL and IADL the } \\
\text { authors investigated the } \\
\text { number and severity of } \\
\text { functional limitations } \\
\text { - Religiosity: direct } \\
\text { question about the } \\
\text { performance of any of } \\
\text { these positions: deacon, } \\
\text { elder, counselor, pastor } \\
\text { or minister, committee } \\
\text { chair, choirmaster, or } \\
\text { Sunday Bible School } \\
\text { teacher }\end{array}$ & $\begin{array}{l}\text { 1,152 American } \\
\text { elderly persons living } \\
\text { in the community } \\
\text { - Representative } \\
\text { sample of elderly } \\
\text { population of USA } \\
\text { (excluding Hawaii } \\
\text { and Alaska) }\end{array}$ & $\begin{array}{l}\text { Elderly men with a } \\
\text { religious leadership } \\
\text { position had a slower } \\
\text { and less aggressive } \\
\text { functional decline } \\
\text { trajectory than those } \\
\text { with no leadership } \\
\text { roles }(p=0.009) \\
\text { and non-frequenters } \\
(p=0.004) .\end{array}$ \\
\hline
\end{tabular}

The samples of the studies were varied. Three $\operatorname{articles}^{14-16}$ were conducted with American elderly persons living in the community, one with diabetic rural elderly persons from different ethnic groups (American, African American and white) ${ }^{13}$, one with institutionalized Hispanic elderly persons (of Mexican origin) who had suffered a stroke ${ }^{12}$ and one with elderly Brazilians registered with a Basic Health Unit ${ }^{3}$.

In two articles ${ }^{12,15}$ the authors included in the evaluation of functional capacity, as well as the analysis of daily activities, the evaluation of aspects of mobility, such as lower limb strength and gait.

All six articles indicated a significant association between the religiosity and functional capacity of the elderly, revealing its beneficial and protective influence on functionality. Religiosity was associated with functional capacity in three different forms: coping with disability ${ }^{3}$, improved functional capacity ${ }^{13,14}$ and delayed functional decline $e^{12,15,16}$. Different aspects of religiosity displayed an association with functional capacity, such as: participation in religious 
activities $^{12-15}$, a position of religious leadership ${ }^{16}$ and religious beliefs and traditions ${ }^{3}$.

In three articles ${ }^{13-15}$, the positive association of religiosity with functional capacity was linked only to public religious activities, whether organized or non-organized, and not intrinsic religious practices such as prayers and readings.

\section{DISCUSSION}

Religiosity positively affects physical and mental health, promoting successful aging ${ }^{17}$. Many elderly persons attribute a special value to religiosity in relation to the improvement of their condition, considering that it contributes to quality of life, wellbeing, and social and psychological integration ${ }^{1}$. In addition, one study ${ }^{3}$ included in this review identified an association between religiosity and coping with disability, meaning that it is a valuable resource for the acceptance of common losses in aging, such as the loss of functional independence ${ }^{18}$.

According to Santos et al. ${ }^{3}$, coping responses are alternatives where the negative element is controlled. Religious beliefs and behaviors therefore help the elderly to cope with the suffering experienced in functional dependence, and serve to facilitate problem solving and prevent or alleviate negative emotional consequences.

In the coping process, the individual plays an active role, using religious resources as an aid to reduce anxiety, increase hope, and broaden the meaning of existence. Religious involvement can provide an increased sense of purpose and meaning in life, which is associated with a greater capacity to respond positively to the demands of everyday life. In addition, meditations and prayers enable the mind to focus on other things, diverting thought away from problems and afflictions ${ }^{18,19}$.

The spiritual support of people in the religious community is also a positive resource for coping with the effects of functional disability, as it provides the elderly with a manner of restructuring physical health problems by helping them find meaning in the face of such adversity. A study of 583 elderly Americans showed that those with a high level of spiritual support had gains in personal control when dealing with functional dependence ${ }^{20}$.
Other authors identified greater social support ${ }^{21}$ and more positive forms of religious coping ${ }^{22}$ in individuals with religious leadership roles, which in this review was associated with a slower functional decline ${ }^{16}$. According to Hayward and Krause ${ }^{16}$, religious leadership can contribute to successful aging by providing a sense of purpose and positive selfimage; in addition, the personal value generated by group leadership provides the motivation to engage in healthier behavior in order to remain active in the role, and potentially reduces the stress and depression associated with a loss of roles, thereby reducing their impact on physical health.

The association between religiosity and improved functional capacity described in two articles included in this review ${ }^{13,14}$ is corroborated by the findings of a previous review ${ }^{17}$ that showed benefits of religiosity in the physical and functional evolution of hospitalized elderly persons, as well as a positive correlation between spirituality and functionality in adults in rehabilitation. In contrast, the study by Santos and Abdala ${ }^{18}$, which evaluated the relationship between religiosity and the dimensions of healthrelated quality of life among the elderly, did not find any association between religiosity and the "functional capacity" dimension.

Moraes and Souza ${ }^{19}$, however, found that elderly persons whose personal beliefs gave more meaning to life had up to a tenfold greater chance of experiencing a successful aging process. According to Luccheti et al. ${ }^{17}$, religiosity is one of the determining factors of successful aging, which encompasses high physical functioning and the absence of functional disability. It can therefore be inferred that religiosity, by positively influencing successful aging ${ }^{20}$, also influences the improvement of functional capacity.

Other benefits to the elderly have been attributed directly to religiosity, such as a reduced fear of falling ${ }^{21}$, a lower prevalence and slower evolution of neuropsychiatric diseases ${ }^{17}$, and greater adherence to medical treatments and preventive care ${ }^{22}$, which also contributes to better functional capacity ${ }^{23,24}$.

The association between religiosity and the delay in functional decline identified in some of the studies ${ }^{12,15,16}$ in this review can be justified by the fact that elderly people with religious beliefs are more 
likely to adopt healthy habits and reduce alcohol and cigarette intake ${ }^{1,25}$, which makes them less exposed to risk factors for chronic diseases that anticipate the loss of functionality, such as diabetes ${ }^{26}$, arterial hypertension, heart and lung diseases ${ }^{27}$, thus delaying functional decline. Ratifying this idea, studies have already shown a lower index of cardiovascular diseases $^{28}$ and depression ${ }^{29}$ among the elderly who engage in religious and spiritual activities. Thus, religiosity seems to protect the elderly against chronic diseases that accelerate functional decline.

Four articles ${ }^{12-15}$ included in this review identified an association between participation in religious activities and a better performance in BADL and IADL. Corroborating our findings, previous studies have shown that religiosity is closely linked to factors such as community participation, socialization and well-being ${ }^{17,30}$ and these factors have previously been associated with a better performance in BADL and $\mathrm{IADL}^{7,31}$. This suggests that by producing such psychosocial benefits among the elderly, religiosity contributes to greater independence in daily activities.

While participating in social and leisure activities themselves also provides these psychosocial benefits ${ }^{32}$, religiosity goes further than social participation as it is associated with intrinsic religious practice ${ }^{13,15}$. Some authors ${ }^{33,34}$ have identified the benefits of intrinsic practices such as prayer and meditation in coping with chronic diseases and pain, generating feelings of well-being and relaxation. Another study ${ }^{4}$ found that a higher level of intrinsic religiosity was associated with an improved mental component and quality of life in the elderly. However, although intrinsic religiosity brings benefits to aspects associated with functionality ${ }^{21,24,35}$, three studies ${ }^{13-15}$ found no association between functional capacity and intrinsic religious practice.

A possible hypothesis for the non-association of intrinsic religiosity with functional capacity may be the fact that elderly persons who describe a greater participation in intrinsic religious practices are those with inferior functionality, as functional decline intensifies with increasing age. There is then a tendency to reduce participation in formal religious activities, due to physical and functional limitations. To compensate for non-attendance at church, temples and organized events, the elderly individuals end up spending more time on intrinsic religious activities ${ }^{18}$.

The association between the greater frequency of intrinsic religious practices and functional decline, together with the association between intrinsic religiosity and functional capacity, remain unclear, however. Comparative studies of the functionality of elderly people who attend religious activities and those who frequent social activities are also necessary to clarify whether both activities have the same effect on the functional capacity of the elderly.

This study presents certain limitations, such as the scarcity of Brazilian articles, meaning that the analysis is largely based on samples of American elderly persons. Another limitation to be considered is that there was no standardization in the instruments of the evaluation of religiosity, which may result in different interpretations of the term "religiosity" by different authors.

This article does not consider a specific type of religion, but rather the benefits of religious activities for functional capacity.

\section{CONCLUSION}

Based on this review, it can be concluded that religiosity is associated with improved functional capacity, delayed functional decline and more effective coping with disability.

Religious beliefs and traditions, participation in religious activities, and leadership performance were aspects of religiosity that were associated with functional capacity.

Despite generating well-being among the elderly, the association of intrinsic religiosity with functional capacity is still unclear.

More studies are therefore needed to clarify the real association between functional capacity and intrinsic religiosity, as well as a greater appreciation of religious aspects by all professionals who deal directly with the elderly, so that the psychosocial dimension is considered in the care of this population and the principle of integrality in the Unified Health System is respected. 


\section{REFERENCES}

1. Araújo MFM, Almeida MI, Cidrack ML, Queiroz HMC, Pereira MCS, Menescal ZLC. O papel da religiosidade na promoção da saúde do idoso. Rev Bras Promoç Saúde. 2008;21(3):201-8.

2. Organização Mundial de Saúde. Envelhecimento ativo: uma política de saúde. Brasília: OPAS; 2005.

3. Santos WJ, Giacomin KC, Pereira JK, Firmo JOA. Enfrentamento da incapacidade funcional por idosos por meio de crenças religiosas. Ciênc Saúde Coletiva. 2013;18(8):2319-28.

4. Abdala GA, Kimura M, Duarte YAO, Lebrão ML, Santos B. Religiosidade e qualidade de vida relacionada à saúde do idoso. Rev Saúde Pública. 2015;49(55):1-9.

5. Krause N. Exploring the stress-buffering effects of church-based and secular social support on selfrated health in late life. J Gerontol Ser B Psychol Sci Soc Sci. 2006;61(1):35-43.

6. Hummer RA, Ellison CG, Rogers RG, Multon $\mathrm{BE}$, Romero RR. Religious involvement and adult mortality in the United States: review and Perspective. South Med J. 2004; 97(12):1223-30.

7. Kagawa CA, Corrente JE. Análise da capacidade funcional em idosos do município de Avaré-SP: fatores associados. Rev Bras Geriatr Gerontol. 2015;18(3):577-86.

8. Oliveira AM, Garcia PA. Perfil demográfico, clínico e funcional de idosas participantes e não participantes de atividades comunitárias ligadas à igreja. Rev Ter Ocup. 2011;22(2):153-61.

9. Matos IE, Carmo CN, Santiago LM, Luz LL. Factors associated with functional incapacity in elders living in long stay institutions in Brazil: a cross-sectional study. BMC Geriatrics. 2014;14(47):2-9.

10. Nogueira SL, Ribeiro RCL, Rosado LEF, Franceschini SC, Ribeiro AQ, Pereira ET. Fatores determinantes da capacidade funcional em idosos longevos. Rev Bras Fisioter. 2010;14(4):322-9.

11. Higgins JPT, Green S. Cochrane Handbook for systematic reviews of interventions. Chichester: John Wiley \& Sons; 2006.

12. Berges IM, Kuo Y, Markides KS. Attendance at religious services and physical functioning after stroke among older mexican americans. Exp Aging Res. 2007;33:1-11.

13. Hybels C, Blazer D, George L, Koenig H. The Complex Association between religious activities and functional limitations in older adults. Gerontologist. 2012;52(5):676-85.
14. Park NS, Klemmack D, Roff L, Parker M, Koenig $\mathrm{H}$, Sawyer $\mathrm{P}$, et al. Religiousness and longitudinal trajectories in elders functional status. Res Aging. 2008;30(3):279-98.

15. Arcury T, Stafford J, Bell R, Golden S, Snively B, Quandt S. The association of health and functional status with private and public religious practice among rural, ethnically diverse older adults with diabetes. J Rural Health. 2007;23(3):246-53.

16. Hayward D, Krause N. Voluntary leadership roles in religious groups and rates of change in functional status during older adultthood. J Behav Med. 2014;37(3):543-52.

17. Lucchetti G, Lucchetti ALG, Bassi RM, Nasri F, Nacif SAP. O idoso e sua espiritualidade: impacto sobre diferentes aspectos do envelhecimento. Rev Bras Geriatr Gerontol. 2011;14(1):159-67.

18. Santos NC, Abdala GA. Religiosidade e qualidade de vida relacionada à saúde dos idosos em um município na Bahia, Brasil. Rev Bras Geriatr Gerontol. 2014;17(4):795-805.

19. Moraes JFD, Souza VBA. Factors associated with the successful aging of the socially-active elderly in the metropolitan region of Porto Alegre. Rev Bras Psiquiatr. 2005;27(4):302-8.

20. Dendena A, Dallazen CC, Lyra LR, Tosi PC. Religiosidade e envelhecimento bem-sucedido. Unoesc Ciênc. 2011;2(2):184-97.

21. Reyes-Ortiz CA, Ayele H, Mulligan T, Espino DV, Berges IM, Markides KS. A Higher church attendance predicts lower fear of falling in older Mexican-Americans. Aging Ment Health. 2006;10(1):13-8.

22. Alves LC, Leimann BCQ, Vasconcelos MEL, Carvalho MS, Vasconcelos AGG, Fonseca TCO, et al. A influência das doenças crônicas na capacidade funcional dos idosos do Município de São Paulo, Brasil. Cad Saúde Pública. 2007;23(8):1924-30.

23. Utida KAM, Budib MG, Batiston AP. Medo de cair associado a variáveis sociodemográficas, hábitos de vida e condições clínicas em idosos atendidos pela Estratégia de Saúde da Família em Campo GrandeMS. Rev Bras Geriatr Gerontol. 2016;19(3):441-52.

24. Boström G, Conradsson M, Rosendahl E, Nordström P, Gustafson Y, Littbrand H. Functional capacity and dependency in transfer and dressing are associated with depressive symptoms in older people. Clin Interv Aging. 2014;4(9):249-56. 
25. Abdala GA, Rodrigues WG, Torres A, Rios MC, Brasil MS. A religiosidade/espiritualidade como influência positiva na abstinência, redução e/ou abandono do uso de drogas. REVER. 2010;77-98.

26. Barbosa BR, Almeida JM, Barbosa MR, RossiBarbosa LAR. Avaliação da capacidade funcional dos idosos e fatores associados à incapacidade. Ciênc Saúde Coletiva. 2014;19(8):3317-25

27. Alves LC, Leimann BCQ, Vasconcelos MEL, Carvalho MS, Vasconcelos AGG, Fonseca TCO, et al. A influência das doenças crônicas na capacidade funcional dos idosos do Município de São Paulo, Brasil. Cad Saúde Pública. 2007;23(8):1924-30.

28. Lucchetti G, Granero AL, Nobre F, Avezum Jr A. Influência da religiosidade e espiritualidade na hipertensão arterial sistêmica. Rev Bras Hipertens. 2010;17(3):186-8.

29. Bekelman DB, Sydney MD, Becker DM, Wittstein IS, Hendricks DE, Yamashita TE. Spiritual well-being and depression in patients with heart failure. J Gen Intern Med. 2007;22(4):470-7.

Received: June 21, 2017

Reviewed: August 24, 2017

Accepted: September 02, 2017
30. Chaves LJ, Gil CA. Concepções de idosos sobre espiritualidade relacionada ao envelhecimento e qualidade de vida. Ciênc Saúde Coletiva. 2015;20(12):3641-52.

31. Ribeiro DKMN, Lenardt MH, Michel T, Setoguchi LS, Grden CRB, Oliveira, E.S. Fatores contributivos para a independência funcional de idosos longevos. Rev Esc Enferm USP. 2015;49(1):89-95.

32. Santos PM, Marinho A, Mazo GZ, Hallal PC. Atividades no lazer e qualidade de vida de idosos de um programa de extensão universitária em Florianópolis (SC). Rev Bras Ativ Fis Saúde. 2014;19(4):494-503.

33. Rocha ACAL, Ciosak SI. Doença Crônica no Idoso: espiritualidade e enfrentamento. Rev Esc Enferm USP. 2014;48(2):87-93.

34. Santos ARM, Miranda AS, Ritti-Dias RM, Freitas CMSS. Limitações para caminhar em idosos com claudicação intermitente: a religiosidade como mecanismo de superação da dor. Rev Bras Geriatr Gerontol. 2014;17(2):363-71.

35. Tavares DMS, Dias FA. Capacidade funcional, morbidades e qualidade de vida de idosos. Texto contexto Enferm. 2012;21(1):112-20. 